\section{Retreatments must be included in the evaluation of device performance}

We would like to comment on the conclusions of the recent paper reporting the 3 year follow-up results of the Webcast studies': 'This analysis confirms the high safety profile of WEB...the great stability of aneurysm occlusion in $83.6 \%$ of aneurysms'.

It is not easy to criticize a manuscript written by 17 experts, including many prominent leaders of the neurovascular field and several close friends, particularly one where superlatives ('high safety' and 'great stability') and 'GCP' $(\mathrm{n}=8)$ are used repeatedly. Yet, as true friends, we must tell the 'ugly truth': 10 years after its introduction, the evidence supporting the use of WEB in the treatment of aneurysms (mainly small unruptured aneurysms) is weak; a case series of 100 or so highly selected patients, recruited in no fewer than 15 high volume centers, with anatomical results in less than $60 \%$ of patients. The lack of detailed information regarding the adjudication of results (how, by whom, independence, blinding, reliability, etc...) is disturbing, particularly when one looks at the two examples provided: both are adjudicated as complete occlusions, while one obviously shows aneurysm filling (figure 1) and the other a residual neck (figure 2) that would have been obvious had the figure not been inverted (left-right). Some of the design choices can be debated (such as not reporting 'minor complications', the
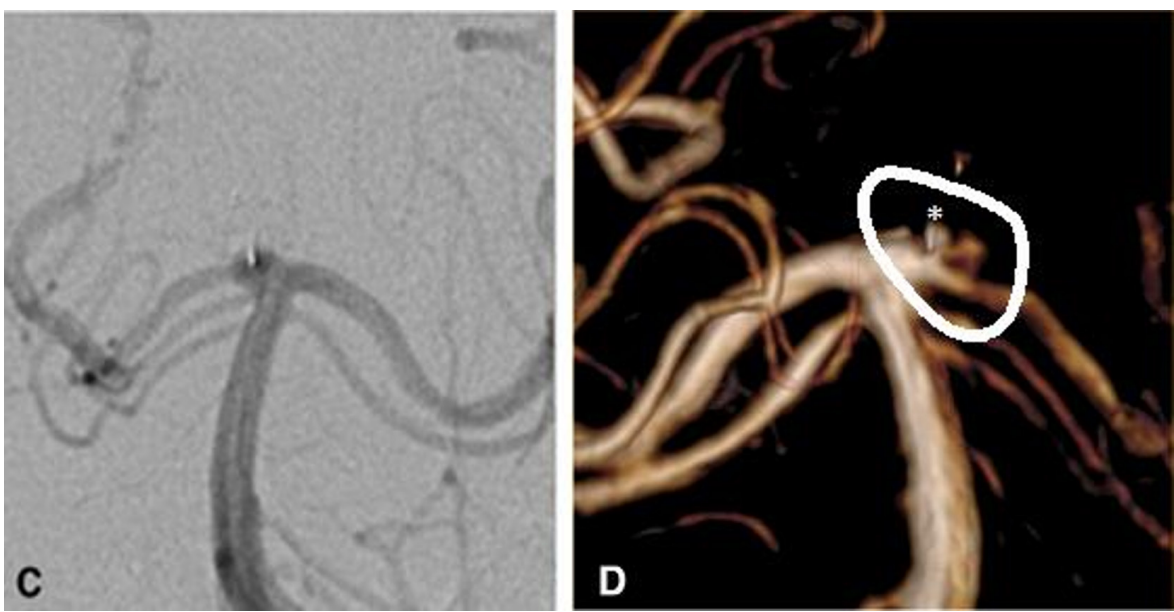

Figure 2 (A) (2C in original text): 1 year follow-up demonstrating a recess at the origin of the right PCA following WEB placement without neck remnant. The basilar artery is shown in the usual anteroposterior projection with a duplicated right superior cerebellar artery. (B) (2D in original text): 3-year MRA follow-up. The basilar artery is now presented in posteroanterior projection. A lateral recanalization is clearly present, differentiated from the original recess, the latter being defined by the position of the more medial radiopaque detachment marker * ${ }^{*}$ MRA, magnetic resonance angiography; PCA, posterior cerebral artery.

exclusion of initial failures but the inclusion of patients treated with coils/stents/ flow diversion in addition to the WEB, the use of a classification system that considers residual filling near the recess of the device a complete occlusion); however, the exclusion 'per protocol' from the evaluation of the performance or efficacy of a new device patients that had to be retreated 'between the index procedure and before follow-up' is just plain wrong. When these nine patients are added to the 10 patients who had a residual aneurysm at follow-up, the results are no better than those of most coiling studies that typically include more

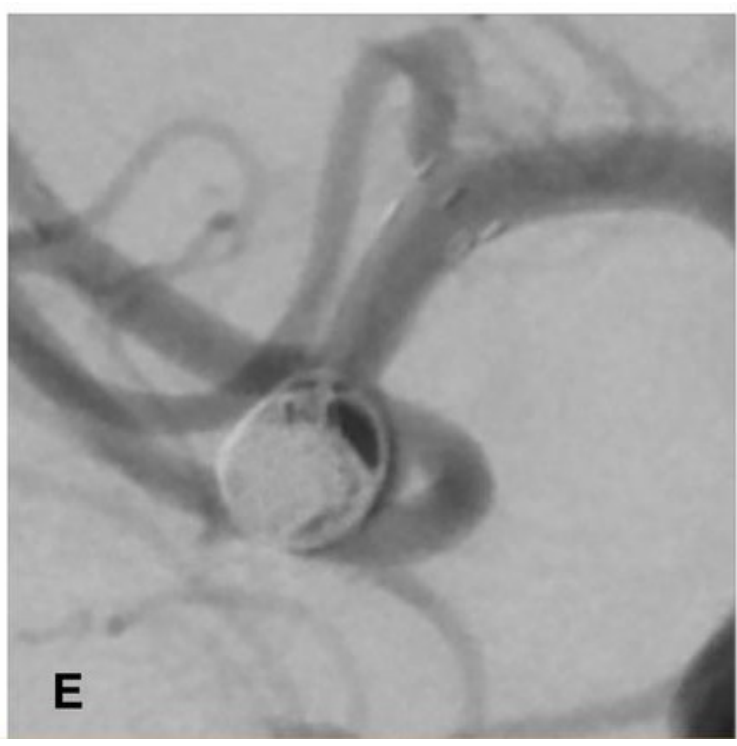

Figure 1 (3E in the original text) showing a treated MCA aneurysm that was judged completely occluded. A residual aneurysm is clearly visible. MCA, middle cerebral artery. ruptured and large aneurysms than the present study, and one can hardly understand the enthusiastic conclusion on WEB performance.

We have once more collectively failed to properly evaluate our work. In that respect, the WEB is no worse than all other endovascular innovations. $^{2-4}$ This way of introducing innovations has already and repeatably proven its inability to guide clinical practice. A trial is in order. ${ }^{5}$

\section{René Chapot $\odot,{ }^{1}$ Pascal J Mosimann, ${ }^{1}$} Tim E Darsaut, ${ }^{2}$ Jean Raymond ${ }^{3}{ }^{3}$

'Department of Neurointerventional Therapy, Alfried Krupp Hospital Trust, Essen, Germany

'University of Alberta Hospital, Edmonton, Alberta, Canada

${ }^{3}$ Radiology, CHUM, Montreal, Quebec, Canada

Correspondence to Dr René Chapot, Department of Interventional and Diagnostic Neuroradiology, Alfried Krupp Hospital, Essen 45131, Germany; Rchapot@ icloud.com

Contributors The entire manuscript is fully and equally coauthored.

Funding The authors have not declared a specific grant for this research from any funding agency in the public, commercial or not-for-profit sectors.

Competing interests None declared.

Patient consent for publication Not required.

Provenance and peer review Not commissioned; internally peer reviewed.

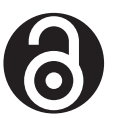

\section{OPEN ACCESS}

Open access This is an open access article distributed in accordance with the Creative Commons Attribution 


\section{Letter}

Non Commercial (CC BY-NC 4.0) license, which permits others to distribute, remix, adapt, build upon this work non-commercially, and license their derivative works on different terms, provided the original work is properly cited, appropriate credit is given, any changes made indicated, and the use is non-commercial. See: http:// creativecommons.org/licenses/by-nc/4.0/.

RC and PJM are joint first authors.

\section{A) Check for updates}

To cite Chapot R, Mosimann PJ, Darsaut TE, et al. J Neurolntervent Surg 2021;13:e5.

Accepted 19 August 2020

\section{Dinked}

- http://dx.doi.org/10.1136/neurintsurg-2020-016773 - http://dx.doi.org/10.1136/neurintsurg-2020-016151

J Neurolntervent Surg 2021;13:e5. doi:10.1136/neurintsurg-2020-016619

\section{ORCID iDs}

René Chapot http://orcid.org/0000-0002-2584-8361 Jean Raymond http://orcid.org/0000-0003-1978-4274

\section{REFERENCES}

1 Pierot L, Szikora I, Barreau X. Aneurysm treatment with web in the cumulative population of two prospective, multicenter series: 3-year follow-up. J Neurointerv Surg 2021;13:363-8.

2 Raymond J, Darsaut TE. Stenting for intracranial aneurysms: how to paint oneself into the proverbial corner. AJNR Am J Neuroradio/ 2011;32:1711-3.

3 Fahed R, Darsaut TE, Raymond J. The introduction of innovations in neurovascular care: patient selection and randomized allocation. World Neurosurg 2018:118:e99-104.

4 Raymond J, Fahed R, Roy D, et al. The 2018 TER Brugge Lecture: problems with the introduction of innovations in neurovascular care. Can J Neurol Sci 2019:46:151-8.

5 Raymond J, Januel A-C, lancu D, et al. The RISE trial: a randomized trial on intra-saccular endobridge devices. Interv Neuroradiol 2020;26:61-7. 